\title{
SUSTAINABLE DEVELOPMENT IN CHINA AND RUSSIA: COMPARATIVE LEGAL RESEARCH
}

\author{
FANGKUN XIN, \\ Shanghai University of Political Science and Law (Shanghai, China) \\ NINA SYMANIUK, \\ Ural Federal University (Yekaterinburg, Russia)
}

https://doi.org/10.21684/2412-2343-2021-8-2-152-167

This article examines the specifics of legal regulation of sustainable development in China and Russia. This topic is exceptionally relevant today since legal regulation of this area should create effective frameworks for the relationship between people and nature. The authors draw attention to the fact that sustainable development is better implemented when it is supported both by international standards and, necessarily, by national laws. The approaches then that China and Russia, both member countries of the $B R I C S$ bloc, are taking in implementing sustainable development are of importance, and thus described and contrasted in this study. To do so, the authors apply the comparative legal analysis, which makes it possible to distinguish both the advantages of international and national systems and the disadvantages. Based on their methodology, the authors formulate possible recommendations for each nation.

Keywords: sustainable development; comparative research; legal regulation; China; Russia.

Recommended citation: Fangkun Xin \& Nina Symaniuk, Sustainable Development in China and Russia: Comparative Legal Research, 8(2) BRICS Law Journal 152-167 (2021). 


\section{Table of Contents}

\section{Introduction}

\section{Methodology}

2. Overview of the Chinese Legal System

3. Legal Regulation of Sustainable Development in China

4. The Environmental Protection Law of the People's Republic of China

5. Concept of Sustainable Development in Russian Legislation Conclusion

\section{Introduction}

The concept of sustainable development was a logical outgrowth of the greening of scientific knowledge and socio-economic development that rapidly gained momentum in the 1970s. In that period, much concern and research centered around the issues of limited natural resources and pollution of the natural environment, in the realization that nature is the basis of economic and all other forms of human activity, and, in fact, the basis of life itself. The response to this concern was the creation of international non-governmental scientific organizations for the study of global processes and their effects on the planet, such as the International Federation of Institutes for Advanced Research (IFIAS), the Club of Rome (with its report "The Limits to Growth") and the International Institute for Systems Analysis. The 1972 United Nations Conference on Human Environment in Stockholm and the creation of the United Nations Environment Programme (UNEP) marked the inclusion of the international community at the state level in addressing environmental issues that had already begun to hinder socioeconomic development. Environmental policy and diplomacy, environmental law and a new institutional component - government ministries and departments for the environment - began over time to be put in place in concerted efforts to take effective action on environmental issues.'

In spite of these efforts, natural disasters are increasing in frequency today, a sharp deterioration of the environment is being witnessed, and these processes do not have long-term positive dynamics. Global environmental issues related to climate change, loss of biological diversity, desertification, increasing environmental damage from natural disasters and particularly from man-made disasters, air, land and underground water pollution, as well as the pollution of the marine environment all certainly impact the interests of every country.

Назаретян А.П. О прогнозировании в шутку и всерьез // Историческая психология и социология истории. 2011. № 1. С. 189-209 [Akop P. Nazaretyan, On Forecasting in Jest and in Earnest, 4(1) Historical Psychology \& Sociology of History 189 (2016)]. 
It is clear that policy development in this area calls for new legal regulation at the national level of those states that are involved in the sustainable development agenda. In this article, we offer a comparative study of the legal regulation of sustainable development in China and Russia.

\section{Methodology}

In the last few years, comparative legal research has become widespread. The works in this field can be complex, representing the analysis of the whole legal institution, or they can consider in detail a separate legal category in different legal systems. There are several reasons for using this method. First, comparative law is interdisciplinary and comprehensive in its character, since it includes the study of national law, historical and legal aspects, the political situation and international law. As a result, the particular character of national legal systems become more understandable and several models of legal regulations can be worked out within the overall study. Second, comparative law enables researchers to overcome the narrow angle of perception of the national legal system, thereby allowing them to focus on existing problems and drawbacks. ${ }^{2}$ Moreover, comparative law has the capacity to open the door to achieving purely pragmatic, applied goals and intensify law-making activity aiming to unify and harmonize legal systems.

Often, the subject of a comparative legal research is essentially homogeneous categories that exist in similar legal conditions, have identical prerequisites for formation, etc., which makes it logically possible to determine the criteria for legal comparison. ${ }^{3}$

The question arises then: Is it possible to conduct a comparative legal study of the legal systems of states that can initially be seen as diametrically opposed in their forms, but have a homogeneous character in essence and logic of implementation processes?

This paper attempts to answer that question.

Often, in comparative legal works in which Russia is a country of interest researchers contrast Russia with European states or with the United States, since it is common practice to consider those states to be classic models that offer effective solutions to the most complex legal issues worth focusing on, and thus they should be used as a template for the Russian legal framework. However, in recent times, it is clearly evident that the successful practice of territorial organization of the state can be formed not only in Europe or North America, but also in Asia. For this reason the focus of this comparative legal analysis is two countries of the BRICS bloc - the Russian Federation and People's Republic of China.

2 Alfredo Ferrante, Between Comparative Law and Foreign Law: An Approach to Legal Comparison, 43(2) Revista Chilena de Derecho 601 (2016).

3 Geoffrey Samuel, Comparative Law and its Methodology in Research Methods in Law 122 (Dawn Watkins \& Mandy Burton eds., 2017). 


\section{Overview of the Chinese Legal System}

China is a unique country known for its very early civilization and long and rich history. Throughout their country's historical path, the Chinese people have maintained their conviction in their identity as an independent and self-reliant nation which does not fit into the general logic of country's evolution but follows its own national development trajectory. For a long time, China was widely acclaimed for its creativity and inventions (porcelain, paper, gunpowder, etc.), and the country played an important role in world trade and foreign economic relations. But at the beginning of the twentieth century, the situation changed radically, and the nation quickly turned into one of the most underdeveloped. In 1949, China was a backward, semifeudal and semi-colonial country. The economy was at a stage of deep stagnation, the vast majority of the population lived below the poverty line, and the average life expectancy was about thirty-five years. ${ }^{4}$ This was followed by the "cultural revolution" which led the nation further into an economic impasse, exacerbating social tension as well as tension within the domestic political situation.

In the late 1970s, China began to implement comprehensive reforms in every area of economic development: it introduced market mechanisms and applied diverse banking structures and it provided more autonomy for state-owned enterprises and the private sector. All structural changes to the economy were implemented under the leadership of the Communist Party of China. ${ }^{5}$ The measures taken then, and those taken over the course of subsequent decades, were complex and large-scale; the reforms were comprehensive and based on global intensification. As a result, in 2010, the Chinese economy overtook the Japanese economy and became the second-largest economy in the world in terms of nominal GDP, and in December 2014 the China became the largest economy in the world in terms of purchasingpower adjusted GDP. Currently, China is actively developing the concept of "One Belt - One Road" aimed at improving existing and creating new trade routes and transport and economic corridors connecting more than sixty countries of Central Asia, Europe and Africa, which will contribute to the further development of trade relations between those countries and China. ${ }^{6}$

In political terms, China is a socialist state led by the Communist Party of China. Over the course of many years (not without encountering obstacles and setbacks) party leaders have proven the stability of the chosen way of governing the nation,

4 Васюхин О.В., Хэ В. Развитие экономики Китая // Проблемы и перспективы экономики и управления: материалы III Междунар. науч. конф. (г. Санкт-Петербург, декабрь 2014 г.) [Oleg V. Vasiukhin \&Wei $\mathrm{He}$, Development of the Chinese Economy in Problems and Prospects of Economics and Management: Materials of the III International Scientific Conference (St. Petersburg, 2014)] 230 (2014).

5 Maria A. Carrai, Sovereignty in China: A Genealogy of a Concept Since 1840 121-130 (2019).

6 Стратегия экономического развития «Один пояс - один путь» // РИА Новости. 14 мая 2017 г. [Economic Development Strategy “One Belt - One Road," RIA Novosti, 14 May 2017] (Jun. 11, 2021), available at https://ria.ru/spravka/20170514/1494097368.html. 
which was again recently demonstrated by the holding of the $19^{\text {th }}$ Congress of the Communist Party of China (CPC) in October 2017, during which Xi Jinping was re-elected President of the People's Republic of China, and General Secretary of the CPC Central Committee. In addition, the delegates of the Communist Party of China approved amendments to the party's charter, according to which Xi Jinping's name was included in the text of the main party document, which put him on a par with Mao Zedong and Deng Xiaoping. At the same time, Xi Jinping became the second leader of China after Mao Zedong whose name was included in the party's charter during his lifetime.?

Despite the fact that the political, social and economic development of China and Russia are different, we propose that the achievements of the People's Republic of China can be compared with and applied to the Russian case. To support this proposal, we offer findings from our comparative legal study of these two nations.

One might at first observe that difficulties will arise in the primary fact that Russia is a federation, whereas China, in accordance with the Chinese Constitution, is a unitary state, led by a single party, with a rigidly built centralization of power.

In practice, however, this distinction is not so clear-cut. Article 3 of the Constitution of the People's Republic of China contains the so-called "presumption of competence of local authorities" (the mechanism of presumptions is well known in the Federal Republic of Germany). In its core essence, the Basic Law of the People's Republic of China delegates issues to those levels of government that can resolve them more effectively. This provision of the Chinese Constitution is not purely nominal. Internal relations between the State and its constituent provinces (especially in the economy field) can be considered federal (in particular, with regard to fiscal federalism). In 1994, a tax reform was carried out during which a single value-added tax (VAT) was established amounting to $17 \%$ for all manufacturing firms. Seventy-five percent of the collected VAT went to Beijing, and $25 \%$ went to the local authorities. In the service sector, a business tax of $3 \%$ to $5 \%$ of turnover was introduced, depending on the nature of the business. As a result of the reform, VAT has since become the main source of income for local authorities, creating an opportunity for competition to attract investment, at the expense of infrastructure and the business environment. ${ }^{8}$ This distribution of tax revenues is not common to all federal states, let alone unitary states. Thus, each region, which has its own particular features, tries to develop and maintain its potential, to get more income due to its diversity, and more freedom in the economic sphere. A centralized system in the fields of politics, ideology, social development, etc., does not affect the sphere of the economy and finance; moreover, it encourages the economic independence of the regions and provinces.

Economic Development Strategy, supra note 6.

8 Федерализм из Поднебесной: как Китай стал капиталистическим // Реальное время. 9 сентября 2016 г. [Federalism from the Middle Kingdom: How China Became Capitalist, Real'noe vremia, 9 September 2016] (Jun. 11, 2021), available at https://realnoevremya.ru/analytics/36377. 
In addition, the Constitution of the People's Republic of China allows local entities (municipalities) to create their own legal regulations at the local level, so long as they do not contradict the central legislation of the People's Republic of China. For example, until it was only recently changed, the well-known policy restriction preventing Chinese families from having more than two children did not apply in all provinces. There are a number of provinces whose population includes an ethnic minority where this restriction did not apply (or the restriction was not more than three children).

Special attention should be paid to Article 134 of the Constitution of the People's Republic of China, which stipulates that citizens of all nationalities have the right to use oral and written national language in court proceedings. ${ }^{9}$ The People's Court and the People's Prosecutor Office must provide translation for the participants in the trial if the language is not known to the participants of the trial. The article, which previously fixed the state language, is no longer in force. At the moment, different provinces use their official local languages, which have the status of the state language.

A special case is the status of the Hong Kong Special Administrative Region, which has its own currency (the Hong Kong dollar) and a special status in its relations with the central government (especially in the financial sphere). In addition, in order to enter the territory of Hong Kong, even Chinese citizens need a special permit (a kind of visa that contains information on the date of entry and date of exit and the duration of the stay in the region).

We have mentioned only a few of interesting features of the legal system and state structure of China, which explains one's interest in analyzing the nation from the perspective of a unitary state. Perhaps at the present stage of the development of legal science it is also of value to mention the existence of so-called "diffuse" states, which combine the features of both a federal and a unitary state.

Russia and China share a fairly large number of common characteristics including, for example, large geographical territories and the multinational and multi-religious groups of their populations, which in many respects have a huge impact on the state structure. The countries' particular characteristics and features influence the political processes and the division of government powers, and the relationship between the center and the regional units. In addition, both countries share the experience of communist party governance which also influences their development.

\section{Legal Regulation of Sustainable Development in China}

In China, special attention is paid to the legal regulation of sustainable development. The Chinese Constitution establishes the following provisions: all mineral resources, waters, forests, mountains, meadows, unclaimed land, mudflats

9 Constitution of the People's Republic of China (Jun. 11, 2021), available at http://www.npc.gov.cn/ englishnpc/constitution2019/201911/1f65146fb6104dd3a2793875d19b5b29.shtml. 
and other natural resources belong to the State, that is, to the entire nation and people, with the exception of forests, mountains, meadows, unclaimed land and mudflats, which belong to certain groups in accordance with the law. ${ }^{10}$

The State guarantees the rational use of natural resources and the protection of rare animals and plants. Any company or individual is prohibited from seizing or damaging natural resources by any means. The land in the cities belongs to the State." Land in rural and suburban areas is a collective ownership, except for the land plots owned by the State in accordance with the law; residential plots, arable land and hillsides allocated for private use also belong to collectives.

The State may, in order to satisfy the requirements of the public interest and in accordance with legal provisions, apply expropriation or requisition rules to land and provide compensation. No company or individual has the right to illegally transfer land by seizure, purchase or sale or by any other means. Land-use rights may be transferred only in accordance with the law. All companies and individuals who use land must use it in due diligence. It is also emphasized that the State protects and improves living conditions and the natural environment, as well as prevents and controls pollution and other public hazards. The State organizes and promotes afforestation and forest protection.

Special attention is paid to sustainable development in the Administrative Code of the People's Republic of China implemented on 1 January 2021. The Administrative Code contains a special Chapter VII titled "Liability for Environmental Pollution and Ecological Damage" designed to prevent pollution and damage to the environment under Articles 1229 to 1237; for example, Article 1229 states,

A tortfeasor who has polluted the environment or caused damage to the ecological system bears tort liability. ${ }^{12}$

The Administrative Code also provides rules implementing sustainable development. For example, this regulation is applied to prevent pollution and damage to the marine environment by marine projects under the maritime jurisdiction of the People's Republic of China. Marine projects include the following:

- Marine fencing or filling projects, as well as marine dam projects;

- Projects of artificial islands, storage facilities for materials on the sea and on the seabed, bridges across the sea and tunnels on the seabed;

- Marine pipe and marine electrical (optical) cable projects;

- Projects for the exploration and development of marine mineral resources, as well as ancillary work;

\footnotetext{
10 Constitution of the People's Republic of China, supra note 9.

11 Id.

12 Id.
} 
- Projects of marine tidal power plants, wave power plants, temperature differencebased power plants, and other projects for the operation and use of marine energy;

- Projects of large marine farms and artificial fish reefs;

- Seawater projects such as desalination of salt tanks and seawater;

- Marine entertainment, sports and landscape projects; and

- Other marine projects provided for by the State Marine Administrative Department together with the Administrative Department of Environmental Protection of the State Council. ${ }^{13}$

The State is currently implementing an environmental impact assessment for offshore projects.

The environmental impact assessment of a marine project mainly includes a comprehensive analysis, forecast and assessment of the project's impact on the marine environment and marine resources, appropriate environmental protection measures, and the forecast, control or reduction of the project's impact and damage to the marine environment and marine resources.

The environmental impact assessment report of an offshore project should be prepared in accordance with the technical standards for assessing the environmental impact of offshore projects and other relevant environmental standards. The survey and monitoring materials required by the State Maritime Administration Department are used for the preparation of environmental impact reports.

Where an offshore project may cause damage to the natural environment of the seashore, the environmental impact assessment report should also include an analysis and assessment of the project's impact on nature reserves along the coast and other land-based ecological systems.

China also applies the "polluter pays" principle. When offshore blasting is necessary for the offshore construction, the construction industry must inform the Maritime Administrative Department before the blasting is carried out, and the Department must inform the Administrative Departments of Maritime Affairs and Fisheries in a timely manner.

To carry out blasting operations at sea, easily observable warning signs and signals must be installed and effective measures should be taken to protect marine resources. Blasting operations in large fishing waters or other operations that may cause damage to fish resources should not be carried out during the spawning period of large commercial fish and shrimp areas. In addition, the construction industry, before the offshore project officially begins, must develop an approved emergency response scheme for the prevention and treatment of pollution and damage caused by the offshore project, and present this report for archival registration to the Maritime Administrative Department which initially approved the environmental impact assessment report on the specified project.

13 Environmental Protection Law of the People's Republic of China (Jun. 11, 2021), available at http://www. npc.gov.cn/zgrdw/englishnpc/Special/CombatingClimateChange/2009-08/28/content_1516267.htm. 
According to the Civil Code of the People's Republic of China, in civil activities every person acts in a proper way to conserve natural resources and to protect the environment. ${ }^{14}$

Property owners must comply with laws, regulations and management rules in the area of resource conservation and environmental protection.

In respect of actions that infringe on the legitimate rights and interests of others, such as the arbitrary disposal of garbage, the discharge of pollutants or noise, the feeding and keeping of animals, the construction, encroachment on passageways and refusal to pay property management fees, the owners' meeting or the owners' committee has the right to demand to stop such activities following the enforced rules and regulations, eliminate interference, eliminate danger, restore the original condition and compensate for any losses incurred.

According to the Law of the People's Republic of China on Emergency Response, the principle of prioritizing prevention and combining prevention with emergency response must be observed in emergency situations. The State shall establish a system for assessing the risks of serious emergencies in order to conduct a comprehensive assessment of potential emergencies, to minimize them and to mitigate their consequences. The governments at the district level are responsible for responding to emergencies occurring within their own administrative regions; if two or more administrative regions are involved in an emergency, the responsibility is taken by the higher level government, or the governments of different levels share responsibility. ${ }^{15}$

In an emergency, the government at the district level where the emergency is located should take immediate measures to get the situation under control, to organize rescue operations and other response measures, and to immediately report to the People's Government at the next higher level.

If the government at the district level at the site of the emergency is unable to eliminate or effectively control any serious social damage caused by the emergency, it must promptly inform the People's Government at the next higher level, which will take timely measures and provide unified leadership in dealing with the emergency.

Where laws or administrative regulations provide that the relevant department of the Council of State should assume responsibility for responding to an emergency, such provisions shall prevail; and local authorities should actively cooperate and provide the necessary support.

Thus, our findings are that in China, a fairly large part of the independence and responsibility is given to the local level of governance. China's implementation of sustainable development has been reflected in various regulations since the founding

14 Civil Code of the People's Republic of China (Jun. 11, 2021), available at http://english.mee.gov.cn/ Resources/laws/environmental_laws/202101/t20210115_817614.shtml.

15 Emergency Response Law of the People's Republic of China (Jun. 11, 2021), available at http://english. www.gov.cn/archive/laws_regulations/2014/08/23/content_281474983042515.htm. 
of New China in 1949. After years of development, a comprehensive legal system for sustainable development with the goal of "ecological civilization construction" has been formed. Before 1978, sustainable development in China mainly relied on policy norms issued by state administrative departments or relevant departments of the Party, rather than legal systems. Since the enactment of the Constitution of the People's Republic of China in 1978, the State has made efforts to construct a legal framework for sustainable development, and the relevant basic and specialized legal systems have been successively formulated. From 1978 to 2014, China's regulations for sustainable development have shown a fundamental change from fragmentation to unification. In addition to the Constitution of the People's Republic of China and the "Environmental Protection Law," natural resources legislation related to the development, utilization and protection of natural resources, such as the "Law on the Prevention and Control of Water Pollution," the "Law on the Prevention and Control of Air Pollution," the "Grassland Law" and the "Forest Law," were all completed during this period. Nevertheless, today the Constitution of the People's Republic of China and the "Environmental Protection Law" remain the two most important laws regulating the specific features of sustainable development in China.

\section{The Environmental Protection Law of the People's Republic of China}

In 1979, China enacted the first environmental protection law, the "Environmental Protection Law of the People's Republic of China (for Trial Implementation)." This law was of great significance and provided for substantive transformation from "regulation" to legal frames, which established a reliable legal basis for China's sustainable development.

In 1989, the "Environmental Protection Law of the People's Republic of China (for Trial Implementation)" was amended in response to the needs of economic development and the influence of international thinking on environmental protection. The revised law, the "Environmental Protection Law of the People's Republic of China," reflected China's environmental protection policies at that time and was a significant improvement over the trial law.

In 2014, China's "Environmental Protection Law" was revised for the third time. The revision was more comprehensive in its content, and the role of the law in environmental protection and sustainable development was further highlighted. Compared to the previous law, the main objectives of environmental protection are set out for the first time, namely "promoting ecological civilization construction and promoting sustainable development of an economic society." At the same time, it sets down strict legal liability and other specific rules establishing and improving the legal system for environmental protection.

As one example, Article 4 provides a basic national policy for environmental protection. The State adopts economic and technical policies and measures that are effective for conservation and recycling of resources, protection and improvement 
of the environment and facilitation of harmony between people and nature. In Article 5 , environmental protection is justified by the following principles: prioritized protection, prevention measures, integrated governance, public participation and the "polluter pays" principle.

\section{Concept of Sustainable Development in Russian Legislation}

The first attempts to implement the concept of sustainable development in Russian legislation were made even before the 1992 United Nations Earth Summit in Rio de Janeiro in the Law of the RSFSR "On the Protection of the Natural Environment" (1991). ${ }^{16}$ The preamble of this law stated that nature and its resources are the national heritage of the Russian peoples, the natural basis for their sustainable socio-economic development and well-being. For the first time, it established the right of citizens to a healthy and favorable natural environment, as well as the mechanisms for its implementation. Article 1 of the law provided that the formulated tasks of the environmental legislation of the Russian Federation are implemented in the interests of present and future generations. These norms are consistent with the concept of sustainable development. The law, for the first time, introduced the concept and elements of the economic mechanism of environmental protection, including, in particular, payment for the use of natural resources as well as payment for the negative effects caused by pollution and other types of harm to the environment. Thus, one of the most important principles generally recognized by the international community, the "polluter pays" principle, was set down in Russia's legal system.

In 1992, Russia joined 178 other states in establishing the agreed policy of the global community for sustainable development. Since the United Nations Conference on Environment and Development in Rio de Janeiro Russia has become a party to many multilateral agreements on the conservation of nature (conventions on climate change, biological diversity, protection of the ozone layer, etc.) based on the sustainable approach."

Following the 1992 U.N. agenda, Russia paid more focused attention to sustainable development. The need to develop and implement its concept was stipulated by special Decrees of the Russian President of 4 February 1994 No. 236 "On the State Strategy of the Russian Federation for Environmental Protection and Sustainable Development" ${ }^{\prime \prime 8}$ and 1 April 1996 No. 440 "On the Concept of the Transition of the

16 Закон РСФСР от 19 декабря 1991 г. № 2060-І «Об охране окружающей природной среды» // СПС «КонсультантПлюс» [Law of the RSFSR No. 2060-I of 19 December 1991. On the Protection of the Natural Environment, SPS “ConsultantPlus"] (Jun. 11, 2021), available at http://www.consultant.ru/ document/cons_doc_LAW_189/.

17 Elena Gladun, Sustainable Development of the Russian Arctic: Legal Implications, 12(2) NISP. J. Public Adm. Pol'y 29 (2019).

18 Указ Президента Российской Федерации от 4 февраля 1994 г. № 236 «О государственной стратегии Российской Федерации по охране окружающей среды и обеспечению устойчивого раз- 
Russian Federation to Sustainable Development.".19 The Concept explicitly points to continuity with the principles and approaches formulated by the Rio Declaration on Environment and Development in 1992, and also notes that Russia, on the one hand, has preserved the largest natural ecosystems on the planet and, on the other hand, that the territories where more than half of the country's population lives are characterized as environmentally unfavorable. The main areas of activity envisioned by the Concept are:

- The need to create a legal framework with an emphasis on economic mechanisms for regulating the use of nature and environmental protection;

- The development of a system for stimulating the greening of economic and other activities;

- The assessment of the capacity of local and regional ecosystems; and

- The promotion of sustainable development ideas.

For the first time the concept of "quality of life" appeared in the normative legal act reflecting the elements of the state policy to ensure sustainable development as the most important element among other factors that characterize the wellbeing of people, health, the state of the environment, income, employment and education, and the degree of realization of human rights. However, despite the progressiveness of the enforced Basic Provisions and the Concept of Transition to Sustainable Development, the implementation of the ideas still remains insufficient. For example, in the Decree of 1996 the Government of the Russian Federation there is a demand to take into consideration the Concept when developing forecasts and programs for socio-economic development, when preparing regulatory legal acts and when making economic and other decisions. But these regulations have not been fully implemented. Socio-economic development programs continue to focus primarily on economic indicators. The Russian Government adopted Resolution of 8 May 1996 No. 559"On the Development of a Draft Strategy for Sustainable Development of the Russian Federation." ${ }^{20}$ The state strategy was developed and approved by the Russian Government in December 1997. The issues relating to sustainable development were most fully enshrined in the National Action Plan for Environmental Protection

вития» // СПС «КонсультантПлюс» [Decree of the President of the Russian Federation No. 236 of 4 February 1994. On the State Strategy of the Russian Federation for Environmental Protection and Sustainable Development, SPS “ConsultantPlus"] (Jun. 11, 2021), available at http://www.consultant. ru/document/cons_doc_LAW_3079/.

19 Указ Президента Российской Федерации от 1 апреля 1996 г. № 440 «О Концепции перехода Российской Федерации к устойчивому развитию» // СПС «КонсультантПлюс» [Decree of the President of the Russian Federation No. 440 of 1 April 1996. On the Concept of the Transition of the Russian Federation to Sustainable Development, SPS "ConsultantPlus"] (Jun. 11, 2021), available at http:// www.consultant.ru/cons/cgi/online.cgi?req $=$ doc\&base $=E X P \& n=233558$.

20 Постановление Правительства Российской Федерации от 8 мая 1996 г. № 559 «О разработке проекта государственной стратегии устойчивого развития Российской Федерации» // СПС «Гарант» [Resolution of the Government of the Russian Federation No. 559 of 8 May 1996. On the Development of the Draft State Strategy for Sustainable Development of the Russian Federation, SPS "Garant"] (Jun. 11, 2021), available at http://base.garant.ru/1519644/. 
of the Russian Federation for 1999-2001. However, this plan did not receive the necessary legal action, since only the measures included in it were approved by the order of the State Committee of Ecology of Russia of 31 December 1998 No. 786. The recommendations of international forums on environmental protection and sustainable development were taken into account in the Environmental Doctrine of the Russian Federation, approved by the Decree of the Government of the Russian Federation of 31 August 2002 No. 1225-r. ${ }^{21}$ This document recognizes that the current environmental crisis threatens the possibility of sustainable development of human civilization. The sustainable development of the Russian Federation, the high quality of life and health of its population as well as national security can be ensured only if natural systems are preserved and the appropriate quality of the environment is maintained. To do this, it is necessary to work out and consistently implement a unified state policy in the field of ecology, aimed at protecting the environment and ensuring the rational use of natural resources. ${ }^{22}$ The strategic goal of the state environmental policy is recognized as the preservation of natural systems, maintaining their integrity and life-supporting functions for the sustainable development of society, improving the quality of life, improving the health of the population and the demographic situation, and ensuring the environmental safety of the country. In the Environmental Doctrine, along with the main principles of sustainable development, the basic terms are defined, the objectives, principles and main directions of the state policy in the environmental protection are formulated, and the mechanisms and instruments of its implementation are included. The Environmental Doctrine highlights regional environmental policy as a necessary condition for ensuring sustainable development across the country. This approach is an attempt to empower regional and municipal governments to implement sustainable development principles in the process of legal regulation on regional and municipal levels. The Environmental Doctrine also sets goals of international cooperation - interests of the Russian Federation should be coordinated with global and regional objectives in order to address environmental problems and meet interests of sustainable development in the global community. The provisions of sustainable development are reflected in the Federal Law "On Environmental Protection."The preamble of this law provides for the right of everyone to a favorable environment, which is implemented through the system of environmental rights and obligations. Chapter III "Rights and obligations of citizens, public and non-profit associations in the field of environmental protection" defines natural resources as the basis for sustainable development, life and economic activities

21 Распоряжение Правительства Российской Федерации от 31 августа 2002 г. № 1225-Р «Об Экологической доктрине Российской Федерации» // СПС «КонсультантПлюс» [Order of the Government of the Russian Federation No. 1225-r of 31 August 2002. On the Environmental Doctrine of the Russian Federation, SPS "ConsultantPlus"] (Jun. 11, 2021), available at http://www.consultant.ru/ document/cons_doc_LAW_92097/.

22 For more details, see Elena Gladun \& Olga Zakharova, State Environmental Ideology: From Tsarist Empire to Sustainable Russia, 4(4) BRICS L.J. 39 (2017). 
of Russian citizens. The law articulates state policy in the field of environmental protection, ensures a balanced solution of socio-economic problems, preservation of a favorable environment, biological diversity and natural resources in order to meet the needs of present and future generations. Among the principles of environmental protection, it provides, in particular:

- The human right to a favorable environment;

- Ensuring favorable conditions for human life; and

- Scientifically based combination of environmental, economic and social interests of a person, society and the State in order to ensure sustainable development and a favorable environment.

These and other principles reflect the concept of sustainable development. At the same time, the law contains mechanisms for implementing its main provisions and principles. Article 70 provides for reliable scientific research in the field of environmental protection for the purpose of social, economic and environmentally balanced development of the Russian Federation, creating a scientific basis for environmental protection, developing scientifically based measures to improve and restore the environment, ensuring the sustainable functioning of natural ecological systems, rational use and reproduction of natural resources, and ensuring environmental safety. Thus, the law contains only some basics of the concept of sustainable development and requires improvement of the provisions contained in it in this aspect. The concept of sustainable development is also reflected in other federal environmental laws and laws related to natural resources. For example, paragraph 1 of Article 85 of the Forest Code of the Russian Federation provides for planning use, protection and reproduction of forests (forest planning), which is aimed at ensuring the sustainable development of Russia's territories. Federal Law of 24 April 1995 No. 52-FZ "On the Animal World"23 provides for biological diversity, the sustainable use of all its components, the sustainable existence of the animal world (Art. 2), the protection and use of the animal world, and the preservation and restoration of its habitat is also called for thus ensuring the sustainable existence and sustainable use of the animals (Art. 12). Federal Law of 24 June 1998 No. 89-FZ "On Production and Consumption Waste,"24 provides for a scientifically based combination of environmental and economic interests of the company in order to ensure the sustainable development of the company. Article 5 of Federal Law of 1 May 1999 No. 94-FZ "On the Protection of Lake Baikal" defines the principle of balancing the solution of socio-economic tasks and the tasks of protecting the unique ecological system of Lake Baikal in the interests of sustainable development.

23 Федеральный закон от 24 апреля 1995 г. № 52-Ф3 «О животном мире» // СПС «КонсультантПлюс» [Federal Law No. 52-FZ of 24 April 1995. On the Animal World, SPS “ConsultantPlus"] (Jun. 11, 2021), available at http://www.consultant.ru/document/cons_doc_LAW_6542/.

Федеральный закон от 24 июня 1998 г. № 89-Ф3 «Об отходах производства и потребления» // СПС «КонсультантПлюс» [Federal Law No. 89-FZ of 24 June 1998. On Production and Consumption Waste, SPS "ConsultantPlus"] (Jun. 11, 2021), available at http://www.consultant.ru/document/ cons_doc_LAW_19109/. 
The Urban Planning Code of the Russian Federation of 29 December 2004 No. 190FZ provides for the concept of sustainable development of territories, which means ensuring safety and favorable conditions for human life in the implementation of urban planning activities, limiting the negative impact of economic and other activities on the environment, and ensuring the protection and rational use of natural resources in the interests of present and future generations. ${ }^{25}$ The term "sustainable development" is also used in other laws and regulations. However, there is no consistent focus on ensuring sustainable development in the system of legislative acts of the Russian environmental branch, and other branches, of legislation. In general, Russian environmental legislation lacks unified approaches of a conceptual, strategic and tactical nature with focus on sustainable development. Today in Russia,

Most activities in the field of the environment and development are carried out haphazardly and uncoordinatedly, or there are no mechanisms for ensuring compliance with laws and their timely correction. ${ }^{26}$

Governments should promote sustainable development and its legal frameworks based on sound environmental, social and economic principles, as well as appropriate risk assessments. In the international context of sustainable development, there in the opinion of the global community that Russia needs to move from the declarative proclamation of the concept and principles of sustainable development to its integration into the state strategy, creating mechanisms for its implementation, as well as improving environmental and other legislation on the basis of an integrated approach.

\section{Conclusion}

Based on global environmental trends, and linked by shared natural resources, China and Russia have many similarities in regard to their sustainable development and environmental legislation systems. However, due to the differences in national conditions, development levels and the legal systems of the two countries, the basic laws on environmental protection greatly vary. As a comprehensive basic law of environmental protection, the Russian "Environmental Protection Law" shows the present determination of the Russian Government to protect the environment on the whole, and it lays the legal foundation for the legislation and active participation

25 Градостроительный кодекс Российской Федерации 29 декабря 2004 г. № 190-Ф3 // СПС «КонсультантПлюс» [Urban Planning Code of the Russian Federation No. 190-FZ of 29 December 2004, SPS "ConsultantPlus"] (Jun. 11, 2021), available at http://www.consultant.ru/document/ cons_doc_LAW_51040/.

26 Выпханова Г.В. Понятие и правовое обеспечение концепции устойчивого развития // Вестник Университета имени О.Е. Кутафина. 2019. № 1(17). С. 64-93 [Galina V. Vypkhanova, The Concept and Legal Support of the Concept of Sustainable Development, 1(17) Bulletin of Kutafin University (MSLA) 67 (2016)]. 
of citizens and environmental organizations in environmental protection in the future. Compared with Russia's legislation China's " "Environmental Protection Law" contains some achievements and more comprehensive mechanisms. However, China's "Environmental Protection Law" is more flexible, its negligence often leads to lawsuits and arbitrary processes. Therefore, China and Russia, the world's biggest and most populous countries, should continue to implement sustainable development principles and goals in their national legislation learning from international experience and adopt more efficient laws to contribute to the sustainable development of their territories and the planet.

\section{Acknowledgements}

This article was prepared within the framework of research supported by a grant from the President of the Russian Federation for young scientists No. MK-6113.2021.2 "The State Structure of Russia and China: Comparative Legal Research."

\section{References}

Назаретян А.П. О прогнозировании в шутку и всерьез // Историческая психология и социология истории. 2011. № 1. С. 189-209 [Nazaretyan A.P. On Forecasting in Jest and in Earnest, 4(1) Historical Psychology and Sociology of History 189 (2016)].

Carrai M.A. Sovereignty in China: A Genealogy of a Concept Since 1840 (2019). https://doi.org/10.1017/9781108564861

Ferrante A. Between Comparative Law and Foreign Law: An Approach to Legal Comparison, 43(2) Revista Chilena de Derecho 601 (2016).

Gladun E. \& Zakharova O. State Environmental Ideology: From Tsarist Empire to Sustainable Russia, 4(4) BRICS L.J. 39 (2017). https://doi.org/10.21684/2412-23432017-4-4-39-64

Gladun E. Sustainable Development of the Russian Arctic: Legal Implications, 12(2) NISP. J. Public Adm. Pol'y 29 (2019). https://doi.org/10.2478/nispa-2019-0013

Samuel G. Comparative Law and its Methodology in Research Methods in Law 122 (Dawn Watkins \& Mandy Burton eds., 2017).

\section{Information about the authors}

Fangkun Xin (Shanghai, China) - Associate Professor, School of Government, Shanghai University of Political Science and Law (Shanghai, 201701, China; e-mail: xinnuaa@126.com).

Nina Symaniuk (Yekaterinburg, Russia) - Associate Professor, Department of Theory, Methodology and Legal Support of State and Municipal Management, Institute of Economics and Management, Ural Federal University (19 Mira St., Yekaterinburg, 620002, Russia; e-mail: n.v.symaniuk@urfu.ru). 